\title{
Analisis ekonomi budidaya Ikan Mas (Cyprinus carpio) KJA waduk PLTA Koto Panjang
}

\author{
Dukut Tri Sadono*, Darwis AN, Zulkarnain Umar \\ Program Pascasarjana Ilmu Kelautan Universitas Riau \\ Kampus Bina Widya KM. 12.5 Sp. Panam Pekanbaru \\ *Koresponden E-mail: Dukuttrisadono@gmail.com
}

(Diterima 30 Juni 2020 | Disetujui 03 Januari 2021 |Diterbitkan 30 Januari 2021)

\begin{abstract}
This study aims to analyze the factors that affect income levels, estimate economic value, analyze financial feasibility and study alternative policies for the development of goldfish (Cyprinus carpio) cultivation in floating net cages in an effort to develop fishery potential in Koto Panjang Hydroelectric Reservoir, Kampar Regency, Riau Province. The sampling location is determined based on (purposive sampling). The method used in this research is a survey method. Determination of the population in the study using the Census method. Factors that significantly influence the income of goldfish cultivators (Cyprinus carpio) at the real level $\alpha=5 \%$ are the yield (HP) $\mathrm{kg} /$ unit and the number of cages (JK) unit. The surplus value of goldfish cultivation producers (Cyprinus carpio) is IDR 42,102,269,258.00 / year. The results of the analysis of the financial feasibility value (NPV) of Rp.77,136,617.10, - / unit for the volume of cages $6 \times 6 \times 4$. Whereas for the volume of cages $6 \times 8 \times 4$, it has a value (NPV) which is much greater than Rp. . 173,394,632.39, - I unit. The second value (NPV) is positive based on the criteria for a feasible business investment if the value (Net $B / C$ ) is greater than 1, the value (IRR) is the same as 12.00\% for both cage size categories. The sensitivity analysis shows that the cultivation of goldfish (Cyprinus carpio) KJA in the Koto Panjang Hydroelectric Power Plant is more sensitive to changes in decreased production compared to changes in decreasing price of carp feed (Cyprinus carpio). Based on the Exponential Comparative Analysis (MPE), it is found that the best alternative development policies to be developed and implemented are capital strengthening and improvement of facilities and infrastructure related to fish cultivation development.
\end{abstract}

\section{Keywords: Koto Panjang Hydroelectric Reservoir, financial feasibility, economic value, policy alternatives}

Waduk Koto Panjang terletak pada posisi geografis $100^{\circ} 40^{\prime} \mathrm{BT}-101^{\circ} 00^{\prime} \mathrm{BT}$ dan $00^{\circ} 10^{\prime}$ LU- $00^{\circ}$ 24' LU yang berbatasan langsung dengan Sumatera Barat. Waduk termasuk dalam kecamatan XIII Koto Kampar, dan jarak waduk ke Pekanbaru sekitar 150 $\mathrm{km}$ dan $80 \mathrm{~km}$ dari daerah Bangkinang (BPS Kampar,2010). Upaya pembangunan pada akhirnya bertujuan untuk meningkatkan taraf hidup dan kesejahteraan masyarakat kearah yang lebih baik, yang tercermin dalam peningkatan pendapatan perkapita dan pemenuhan kebutuhan pokok, juga menurunnya angka kemiskinan, memperluas kesempatan kerja dan mengurangi ketimpangan distribusi pendapatan dalam masyarakat (Jhingan, 2004). Menurut Hendrik (2012), Usaha dan potensi pengembangan karamba jaring apung di Waduk PLTA Koto Panjang mempunyai potensi yang cukup besar untuk dikembangkan hal ini disebabkan luasnya perairan waduk mempunyai luas $12.400 \mathrm{Ha}$.

Fungsi utama Waduk Koto Panjang selain berfungsi sebagai Pusat Pembangkit Lisrik Tenaga Air (PLTA), juga sebagai penyuplai kebutuhan listrik perairan Waduk PLTA Koto Panjang juga merupakan nyawa perikanan Riau. Karena hampir $90 \%$ produksi perikanan budidaya Provinsi Riau berasal dari Kabupaten Kampar. Besarnya nilai ekonomis dari budidaya Ikan Mas (Cyprinus carpio) di Waduk PLTA Koto Panjang akan mempengaruhi besar kecilnya pendapatan dan indikator kondisi ekonomi masyarakat sehingga upaya pemberdayaan ekonomi masyarakat menjadi penting untuk mengetahui tingkat kesejahteraannya. Jika budidaya Keramba Jaring Apung dilaksanakan secara optimal di waduk PLTA Koto Panjang maka dapat memberikan manfaat yang lebih tinggi bagi pembudidaya secara ekonomi, sosial, maupun lingkungan. Kegiatan usaha budidaya ikan air tawar di jaring apung inilah, sehingga terjadi perkembangan perekonomian di wilayah sekitar Waduk. Perkembangan perekonomian di sekitar waduk tersebut, tidak hanya sektor budidaya ikan di jaring apung saja, tetapi terjadi pula perkembangan sektor-sektor lain yang terkait dengan budidaya ikan di jaring apung serta sektor-sektor pendukung lainnya, seperti penyediaan benih ikan, pakan ikan, transportasi baik untuk mengangkut benih ikan, pakan ikan, pemasaran ikan, maupun sarana pendukungnya, penyediaan sarana prasarana jaring apung, serta sektor-sektor lain yang dibutuhkan untuk kebutuhan yang terkait dengan keberadaan kolam jaring apung. Jika budidaya Keramba Jaring Apung dilaksanakan secara optimal di waduk PLTA Koto Panjang maka dapat memberikan manfaat yang lebih tinggi bagi pembudidaya secara ekonomi, sosial, maupun lingkungan. Dengan demikian, perlu dilakukan kajian mengenai nilai ekonomi budidaya Ikan Mas (Cyprinus Carpio) pada Keramba Jaring Apung di PLTA Koto Panjang agar dapat dihasilkan suatu kebijakan pengelolaan budidaya dalam Keramba Jaring Apung.

Kegiatan perikanan budidaya kerambah jaring apung masih memiliki peluang untuk dikembangkan. Wiraningsih, (2016) Kualitas air diperoleh bahwa perairan Waduk Koto Panjang masih berada dibawah 
baku mutu air kelas III, sehingga masih bisa dimanfaatkan untuk kegiatan perikanan dan wisata. Kualitas perairan Waduk Koto Panjang masih mendukung kehidupan fitoplankton, zooplanton dan nekton dilihat dari kesuburannya yang menyatakan bahwa Waduk Koto Panjang merupakan perairan yang subur.

Penelitian ini bertujuan untuk menganalisis faktor-faktor yang mempengaruhi tingkat pendapatan pembudidaya Ikan Mas (Cyprinus Carpio), mengestimasi nilai ekonomi budidaya Ikan Mas (Cyprinus Carpio), menganalisis kelayakan finansial usaha budidaya Ikan Mas (Cyprinus Carpio), dan mengkaji alternatif kebijakan pengembangan usaha budidaya Ikan Mas (Cyprinus Carpio) pada Keramba Jaring Apung dalam upaya pengembangan potensi perikanan di Waduk PLTA Koto Panjang Kabupaten Kampar Provinsi Riau. Sedangkan manfaat dari penelitian ini sebagai sumbangan pemikiran alternatif khususnya bagi pembudidaya Ikan Mas (Cyprinus Carpio) dalam Keramba Jaring Apung di Waduk PLTA Koto Panjang Kabupaten Kampar Provinsi Riau, sebagai Sebagai informasi atau masukan bagi pemerintah serta pihak terkait dalam membuat kebijakan pada masa yang akan datang, dan bagi peneliti sendiri bermanfaat sebagai wawasan yang nyata dalam mengimplementasikan ilmu pengetahuan yang diperoleh dengan fenomena yang ada.

\section{BAHAN DAN METODE}

\section{Waktu dan Tempat Penelitian}

Penelitian ini telah dilaksanakan pada Juni 2019 di Waduk PLTA Koto Panjang Kabupaten Kampar Provinsi Riau. Metode yang digunakan dalam penelitian ini adalah metode survey, yaitu dengan cara melakukan peninjauan, pengamatan langsung, pengambilan data informasi langsung ke lapangan dan mengumpulkan data yang berhubungan dengan penelitian. Lokasi sampling di tentukan berdasarkan (purposive sampling) yaitu pada kegiatan usaha budidaya Ikan Mas (Cyprinus carpio) dalam Keramba Jaring Apung di perairan waduk PLTA Koto Panjang.Peta lokasi Penelitian dapat dilihat pada (Gambar.1)

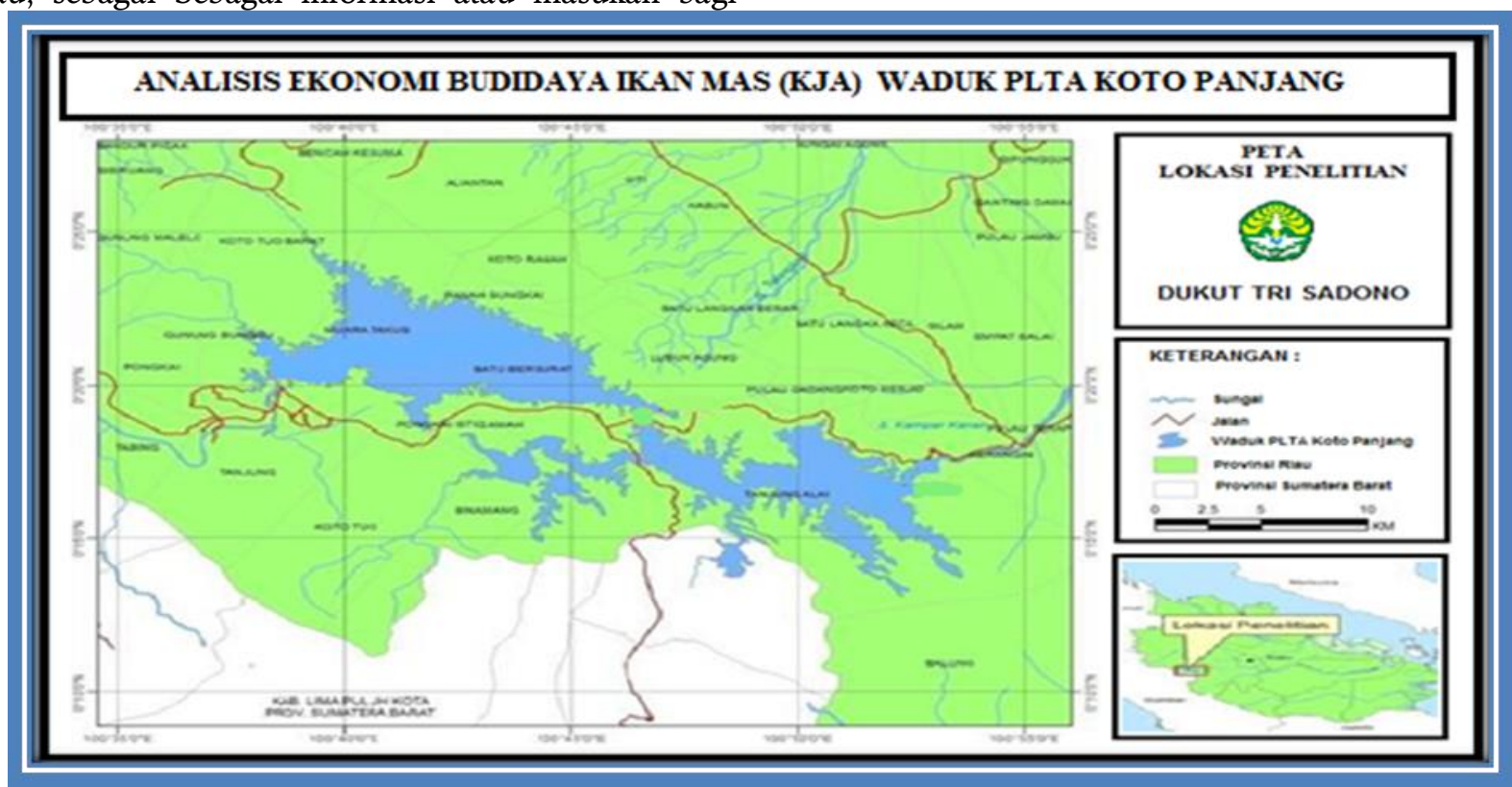

Gambar 1. Peta Lokasi Penelitian

\section{Analisis Data}

Data yang telah diperoleh selanjutnya diolah dan dianalisis secara kualitatif dan kuantitatif sesuai dengan permasalahan yang dikaji. Pengolahan dan analisis data dilakukan dengan menggunakan perangkat lunak (software) IMB SPSS Statistics 21 dan Microsoft Office Excel 2007.

Analisis Faktor - Faktor yang Mempengaruhi Pendapatan Pembudidaya Ikan Mas (Cyprinus carpio) pada Keramba Jaring Apung.

Analisis faktor - faktor yang mempengaruhi pendapatan pembudidaya Keramba Jaring Apung di PLTA Koto Panjang dilakukan dengan membentuk fungsi pendapatan. Berikut ini adalah fungsi pendapatan pembudidaya Keramba Jaring Apung menggunakan model regresi linear:

$$
\mathbf{Y}=\mathbf{a}+\mathbf{V K}+\mathbf{H P}+\mathbf{L U}+\mathbf{J K}+\mathbf{\varepsilon}
$$

Fungsi pendapatan ini dinyatakan dalam satuan waktu satu tahun dengan menggunakan model regresi log linear adalah sebagai berikut:

$$
\mathbf{Y}=\mathbf{a}+\mathbf{L}_{\mathbf{n}} \mathbf{L K}++\mathbf{H P}+\mathbf{L}_{\mathbf{n}} \mathbf{L U}+\mathbf{L}_{\mathbf{n}} \mathbf{J K}+\boldsymbol{\varepsilon}
$$

\section{Keterangan:}

$\mathrm{Y} \quad$ : Pendapatan pembudidaya (Rp/tahun)

a : Intercept

$b_{1} \ldots b_{4} \quad:$ Koefisien regresi yang akan diduga

VK : Volume Keramba $\left(\mathrm{m}^{2}\right)$

HP : Hasil Panen ( $\mathrm{Kg}$ /unit)

LU : Lama Usaha (Bulan)

JK : Jumlah Keramba (Unit)

\& : Galat atau error 
Analisis faktor-faktor berpengaruh terhadap pendapatan pembudidaya dilakukan menggunakan perangkat lunak (software) IMB SPSS Statistics 21.

\section{Kriteria Statistik}

\section{$\mathbf{U j i}^{2}$ (Koefisien Determinasi)}

Menurut Gujarati (2007), $\mathrm{R}^{2}$ menyatakan persentase dari total variabel $\mathrm{Y}$ (dependent) yang dijelaskan oleh variabel $\mathrm{X}$ (independent) dalam model regresi atau mengukur kecocokan dari suatu garis regresi. Nilai $\mathrm{R}^{2}$ dapat dihitung dengan rumus :

$$
R^{2}=\frac{J K R}{J K T}
$$

Keterangan:

$\begin{array}{ll}\mathrm{R}^{2} & \text { : Koefisien Determinasi } \\ \text { JKR } & \text { : Jumlah Kuadrat Regresi } \\ \text { JKT } & \text { : Jumlah Kuadrat Total } \\ \text { Uji F } & \end{array}$

Uji $\mathrm{F}$ dilakukan untuk mengetahui variabelvariabel independent secara keseluruhan dan bersamasama mempengaruhi variabel dependent. Hipotesis yang digunakan adalah :

Ho : Tidak ada pengaruh secara signifikan antara variabel bebas (independent) secara bersamasama terhadap pendapatan serempak tidak berpangaruh nyata terhadap variabel terikat (dependent).

$\mathrm{Ha}$ : Ada pengaruh secara signifikan antara variabel bebas (independent) secara bersama-sama serempak berpangaruh nyata terhadap variabel terikat (dependent). Pengambilan keputusan yang dilakukan adalah: Jika nilai Ho diterima bila $\mathrm{F}$ hitung $<\mathrm{F}$ tabel dan Ho ditolak bila $\mathrm{F}$ hitung $>$ F tabel (Juanda 2009).

\section{Kriteria Ekonometrika Uji Multikolinearitas (Multicolinearity)}

Hasil dari uji multikolinearitas yang dilakukan dapat dilihat dari nilai VIF yang diperoleh. Syarat terpenuhinya asumsi klasik pada uji multikolinearitaas adalah nilai VIF yang dihasilkan dari setiap variabel bebas harus kurang dari 10. Masalah multikolineritas dapat dilihat dari nilai VIF dengan persamaan :

$V I F=\frac{I}{I-R^{2}}$

\section{Uji Normalitas}

Uji normalitas digunakan untuk mengetahui data menyebar normal secara statistik. Uji one sample Kolmogorov-Smirnov digunakan untuk mengetahui seberapa baik sebuah sampel random data mendekati distribusi normal. Hipotesis yang digunakan adalah:

H0: asymp sig $=0$ data menyebar normal

$\mathrm{H} 1$ : asymp sig $\neq 0$ data tidak menyebar normal Keputusan yang diambil adalah: Asymp.sig 2 tailed $>\alpha$ maka terima H0 Asymp.sig 2 tailed $<\alpha$ maka tolak $\mathrm{H} 0$

\section{Uji Heteroskedastisitas}

Uji heteroskedastisitas adalah untuk melihat apakah terdapat ketidaksamaan varians dari residual satu ke pengamatan yang lain. Pengujian dilakukan dengan melihat plot antara residu dengan prediksinya. Jika bentuk sebaran plot tersebut menyebar secara acak dan tidak membentuk suatu pola, maka tidak terjadi heteroskedastisitas.

\section{Uji Autokorelasi}

Autokorelasi merupakan gangguan pada fungsi regresi berupa korelasi diantara faktor gangguan. Uji Durbin-Watson (Uji D-W) merupakan salah satu cara mendeteksi apakah tidak ada autokorelasi yang paling sering digunakan.

\section{Estimasi Nilai Ekonomi}

Analisis pendapatan ialah analisis yang digunakan untuk melihat seberapa besar pendapatan pada usaha pembudidaya Ikan Mas (Cyprinus carpio) di perairan Waduk PLTA Koto Panjang. Pendapatan ( $\boldsymbol{\pi})$ usaha budidaya Ikan Mas (Cyprinus carpio) keramba jaring apung merupakan selisi antara penerimaan (TR) dan semua biaya (TC), dimana penerimaan adalah perkalian antara produksi dan harga jual. Biaya adalah semua pengeluaran yang digunakan dalam suatu usaha, jadi rumus pendapatan dapat dituliskan sebagai berikut (Soekartawi, 2002).

$$
\pi=T R-T C
$$

Keterangan :

$\pi$ :Pendapatan atau keuntungan usaha budidaya (Rp/Tahun)

TR :Total penerimaan kegiatan usaha budidaya (Kg/Tahun)

TC :Total biaya kegiatan usaha budidaya (Rp/Tahun)

\section{Dimana :}

$$
\begin{gathered}
\text { TR }=\mathbf{P} . \mathbf{Q} \\
\mathrm{TC}=\mathrm{FC}+\mathrm{VC}
\end{gathered}
$$

$\mathrm{P} \quad$ : Harga $(\mathrm{Rp} / \mathrm{Kg})$

Q : Produk (Kg/Unit/Tahun)

TC :Total biaya kegiatan usaha budidaya (Rp/Tahun)

FC : Biaya tetap kegiatan usaha budidaya (Rp/Tahun)

VC :Biaya variable kegiatan usaha budidaya

(Rp/Tahun)

Pada penelitian ini dihitung nilai ekonomi pemanfaatan kawasan budidaya Keramba Jaring Apung di waduk PLTA Koto Panjang selama satu tahun dengan pendekatan surplus produsen untuk mengestimasi surplus produsen, diperlukan data variabel biaya-biaya produksi dan pendapatan yang diterima dari barang (Djajanigrat 2011). Secara matematis, dapat dilihat dalam rumus berikut: 
Keterangan:

$$
\boldsymbol{P S}=\boldsymbol{P}_{i} x \boldsymbol{X}_{i}-\mathbf{C}
$$

PS : Surplus produsen (Producer's Surplus) keramba (Rp)

Pi : Harga komoditas i (Rp)

$\mathrm{Xi}$ : Komoditas i $(\mathrm{Kg})$

C. Biaya produksi keramba (Rp)

\section{Analisis Kelayakan Finansial Usaha Ikan Mas (Cyprinus carpio) pada Keramba Jaring Apung}

Perhitungan analisis aspek finansial memerlukan kriteria investasi yang dapat digunakan untuk menyatakan layak atau tidaknya suatu usaha. Kriteria investasi yang digunakan yaitu Net Present Value (NPV), Net Benefit Cost Ratio (Net B/C), Internal Rate of Return (IRR) dan analisis sentifitas.

\section{Net Present Value (NPV)}

Net Present Value (NPV) adalah kriteria investasi yang banyak digunakan dalam mengukur apakah suatu proyek feasible atau tidak. Rumus yang digunakan dalam perhitungan NPV adalah sebagai berikut:

$\mathrm{NPV}=\sum_{t=0}^{n} \frac{B t-C t}{\left(1+i^{t}\right.}$

\section{Keterangan :}

$B_{t}$ :Penerimaan (Benefit) tahun ke - $\mathrm{t}$

$C_{t}$ :Biaya (Cost) tahun ke-t (Rupiah)

$\mathrm{n} \quad$ :Umur proyek (Tahun)

i :Tingkat suku bunga/Discount rate (\%)

$\mathrm{t}$ :Periode (Tahun)

\section{Benefit Cost Ratio (Net B/C)}

Metode menghitung perbandingan antara benefit terhadap cost dalam suatu proyek investasi. Pada proyek-proyek swasta, benefit umumnya berupa pandapatan minus diluar biaya pertama. Misalnya untuk operasi dan produksi sedangkan cost adalah biaya pertama. (Soeharto, 1997) Adapun rumus yangdigunakan adalah:

$$
B C R=\frac{P W B}{P W C}
$$

Keterangan :

BCR : (Benefit Cost Ratio)

PWB : Present Worth of Benefit

PWC : Present Worth of Cost

Apabila didapat nilai BCR sebagai berikut:

$\mathrm{BCR} \geq 1$, proyek layak dilakukan

$\mathrm{BCR}<1$, proyek tidak layak diusahakan

\section{Internal Rate of Return(IRR)}

Internal Rate of Return adalah nilai discount rate yang membuat NPV dari suatu proyek/usaha sama dengan nol. Rumus yang digunakan dalam menghitung IRR adalah sebagai berikut :

$\operatorname{IRR}=i_{1}+\left|\frac{N V P_{1}}{N V P_{1-N P V_{2}}}\right|\left(i_{1}-i_{2}\right)$

Keterangan:

$N P V_{1} \quad$ :NPV yang bernilai positif (Rp)

$N P V_{2} \quad$ :NPV yang bernilai negatif

$i_{1} \quad$ :Discount rate yang menghasilkan

NPV positif (\%)

$i_{2} \quad$ :Discount rate yang menghasilkan

NPV negatif $\%$ )

\section{Analisis Sensitivitas}

Analisis sensitivitas dalam penelitian ini dilakukan untuk mengukur kepekaan perubahan parameter terhadap kelayakan investasi usaha. Parameter perubahan yang digunakan adalah penurunan harga jual ikan mas, dan peningkatan harga jual pakan ikan.

\section{Alternatif Kebijakan Pengembangan Budidaya \\ Keramba Jaring Apung}

Metode Perbandingan Eksponensial (MPE) merupakan salah satu metode untuk menentukan urutan prioritas alternatif keputusan dengan kriteria jamak. Penggunaan MPE dalam alternatif kebijakan pengembangan budidaya Ikan Mas pada Keramba Jaring Apung dilakukan dalam beberapa tahapan yaitu (Marimin \& Maghfiroh, 2010) menyusun alternatifalternatif keputusan yang akan dipilih, menentukan kriteria perbandingan keputusan yang penting untuk dievaluasi, menentukan tingkat kepentingan dari setiap keputusan, melakukan penilaian terhadap semua alternatif pada setiap kriteria, menghitung skor atau nilai total setiap alternatif, dan menentukan urutan prioritas keputusan didasarkan pada nilai total masing - masing alternatif.

Formulasi perhitungan skor untuk setiap alternatif dalam metode perbandingan eksponensial adalah sebagai berikut:

Total Nilai $\left(T N_{i}=\sum_{j=1}^{m}\left(R K_{i j}\right)\right.$ TKKj

Keterangan:

$T N_{i} \quad$ :Total nilai alternatif ke-i

$R k_{i j} \quad$ :Derajat kepentingan relatif kriteria ke-j pada pilihan keputusan $\mathrm{i}$

$T K K_{j}$ :Derajat kepentingan kriteria keputusan ke-j; TKKj > 0; bulat

n :Jumlah pilihan keputusan

m :Jumlah kriteria keputusan

Total skor masing masing alternatif keputusan akan berbeda secara nyata karena adanya fungsi eksponensial (Rangkuti, 2004). 


\section{HASIL DAN PEMBAHASAN}

\section{Faktor - Faktor yang Mempengaruhi Terhadap Pendapatan Usaha Budidaya Ikan Mas (Cyprinus Carpio) Keramba Jaring Apung Waduk PLTA Koto Panjang}

Hasil estimasi regresi faktor - faktor yang mempengaruhi pendapatan Volume Keramba $\left(\mathrm{m}^{3}\right)$, Hasil Panen (Kg/unit), Lama Usaha (Bulan) dan Jumlah Keramba (Unit) Tabel 1.

Tabel 1. Hasil Analisis Regresi Berganda Faktor - Faktor yang Mempengaruhi Pendapatan Usaha Pembudidaya Pembesaran Ikan Mas (Cyprinus Carpio) Keramba Jaring Apung Waduk PLTA Koto Panjang

\begin{tabular}{|c|c|c|c|c|c|}
\hline \multicolumn{6}{|c|}{ Coefficients $^{\mathrm{a}}$} \\
\hline \multicolumn{3}{|c|}{ Unstandardized Coefficients } & \multicolumn{3}{|c|}{ Collinearity Statistics } \\
\hline Model & Coef & SE Coef & T - Value & Sig & VIF \\
\hline (Constant) & 10,480 & 0,100 & 104,361 & 0,000 & \\
\hline VK & 0,004 & 0,005 & 0,814 & 0,421 & 1,035 \\
\hline HP & 0,960 & 0,011 & 87,915 & 0,000 & 1,104 \\
\hline LU & $-0,002$ & 0,002 & $-0,675$ & 0,504 & 2,319 \\
\hline JK & 1,001 & 0,001 & 810,257 & 0,000 & 2,346 \\
\hline
\end{tabular}

$\mathrm{Y}=10,480+0,004 \mathrm{Ln} \mathrm{UK}+0,960 \mathrm{Ln}$ HP 0,002Ln

$\mathrm{LU}+1,001 \mathrm{JK}$

Keterangan:

Y :Pendapatan Pembudidaya (Rp/ Tahun)

VK :Volume Keramba $\left(\mathrm{m}^{3}\right)$

HP :Hasil Panen ( Kg/unit)

LU :Lama Usaha (Bulan)

JK :Jumlah Keramba (Unit)

Berdasarkan hasil regresi linear berganda pada variabel bebas yaitu ukuran keramba, hasil panen, lama usaha dan jumlah keramba merupakan faktor yang diduga berpengaruh terhadap variabel terikat yaitu pendapatan. Hipotesis awal dari masing - masing variabel bebas yaitu volume keramba Ikan Mas (Cyprinus carpio), hasil panen, lama usaha budidaya Ikan Mas (Cyprinus carpio) dan jumlah keramba Ikan Mas (Cyprinus carpio) berpengaruh positif terhadap pendapatan. Berbeda dari hasil penelitian Trisnani, (2013) Faktor - faktor yang mempengaruhi pendapatan usahatani budidaya pembesaran ikan mas dan nila pada KJA ganda di Desa Bobojong untuk satu unit KJA dalam satu tahun antara lain: jumlah produksi ikan mas, jumlah produksi ikan nila, biaya benih ikan mas, harga benih ikan nila, dan harga pakan ikan mas. Berdasarkan hasil analisis dari regresi yang dilakukan maka interpretasi dari masing - masing variabel adalah sebagai berikut:

Setiap volume keramba Ikan Mas (Cyprinus carpio) bertambah satu satuan maka pendapatan akan meningkat sebesar 0,004 .
Setiap hasil panen bertambah satu satuan maka pendapatan akan meningkat sebesar 0,960.

Setiap lama usaha Ikan Mas (Cyprinus carpio) menurun satu satuan maka pendapatan akan meningkat sebesar sebesar 0,002 .

Setiap jumlah keramba Ikan Mas (Cyprinus carpio) meningkat satu satuan maka pendapatan akan meningkat sebesar 1,001 .

Hasil panen erat hubunganya dengan jumlah produksi Trisnani, (2013) Semakin banyak jumlah produksi yang dihasilkan yaitu ikan mas maka akan meningkatkan penerimaan sehingga pendapatan pembudidaya akan meningkat.

Berdasarkan hasil yang diperoleh dapat diketahui nilai VIF dari masing - masing variabel bebas. Uji multikolinearitas dapat dilakukan dengan melihat nilai VIF. Apabila nilai VIF lebih dari 10 berarti pada model terdapat multikolinearitas yaitu terjadinya korelasi yang kuat antar variabel - variabel bebas. Nilai VIF berkisar antara 1,035- 2,346 sehingga dapat disimpulkan dalam model tersebut tidak terjadi multikolinearitas.

Uji normalitas dilakukan dengan melihat normal probability plot dan uji Kolmogorov - Smirnov. Pada Gambar 2 ditunjukkan bahwa titik-titik yang terdapat pada normal probability plot terletak pada suatu garis linier dan berdasarkan hasil statistik KolmogorovSmirnov (KS), nilai KS adalah 0,950 dengan sig melebihi $15 \%$ dan terlihat bahwa nilai KS - hitung lebih kecil dari KS - Tabel, sehingga dapat disimpulkan bahwa data berdistribusi normal. 


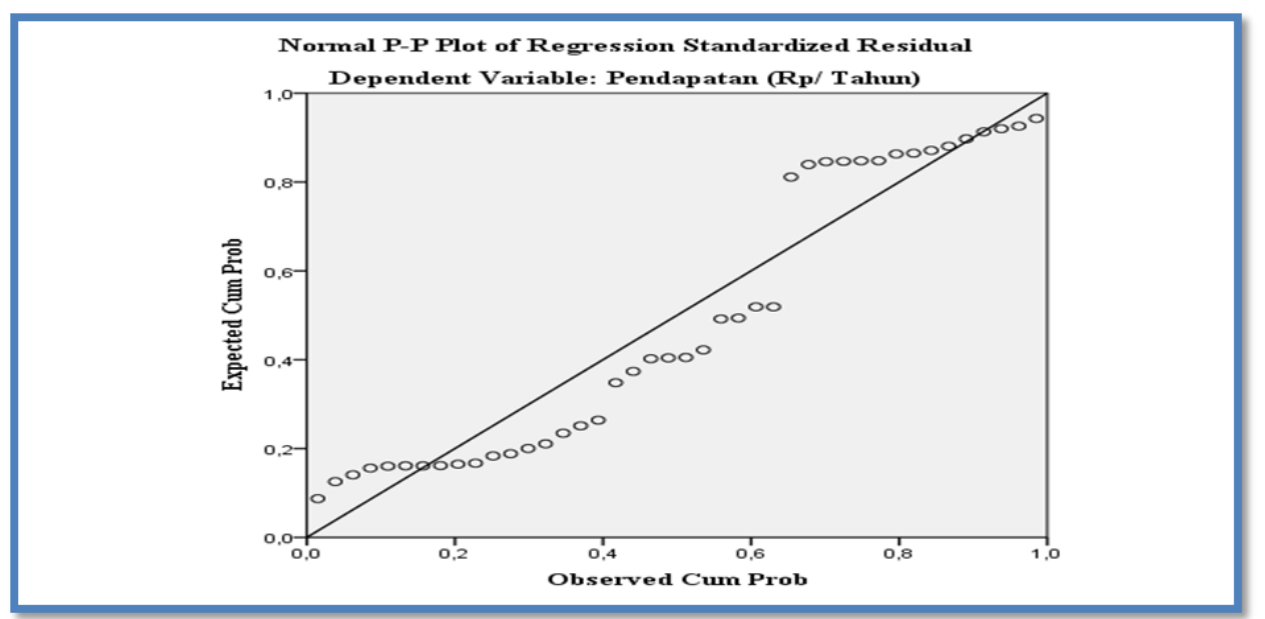

Gambar 2. Normal Probability Plot

Uji heteroskedastisitas dapat dilakukan dengan melihat grafik scatterplot yang dihasilkan. Pendeteksian dapat dilakukan dengan metode grafik, yaitu melihat penyebaran nilai residual yang tidak membentuk suatu pola tertentu, sehingga dapat disimpulkan bahwa asumsi homoskedastisitas dapat dipenuhi. Gambar 3 memperlihatkan bahwa plot uji autokorelasi untuk memastikan tidak ada gangguan pada fungsi regresi linier.

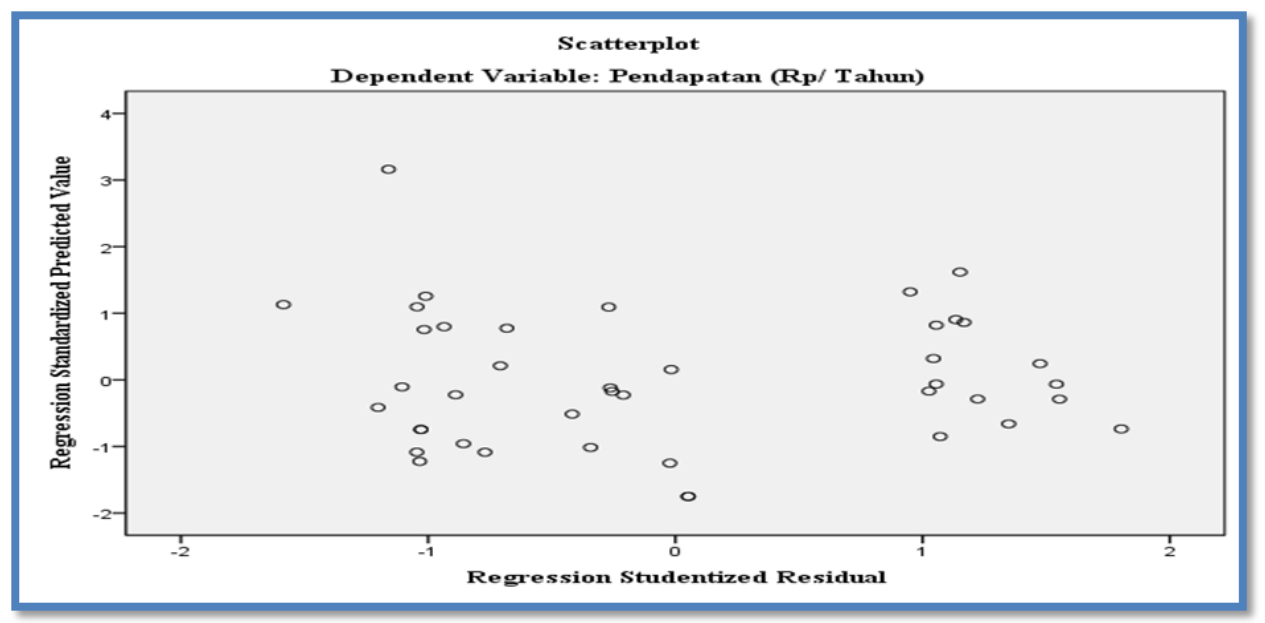

Gambar 3. Plot Uji Heteroskedastisitas

Pendeteksian autokorelasi dilakukan dengan menggunakan statistik Durbin - Watson. menunjukan nilai D - W 2,318. Berdasarkan metode pendeteksian autokorelasi oleh Firdaus (2004), nilai D-W hasil statistik model regresi tidak mengalami pelanggaran asumsi autokorelasi.

\section{Volume Keramba}

Hasil analisis regresi menunjukkan bahwa variabel Volume Keramba berpengaruh terhadap pendapatan usaha budidaya Ikan Mas (Cyprinus carpio) Keramba Jaring Apung waduk PLTA Koto Panjang. Variabel luas keramba berpengaruh signifikan terhadap pendapatan budidaya Ikan Mas (Cyprinus carpio) Keramba Jaring Apung waduk PLTA Koto Panjang pada taraf nyata $\alpha=5 \%$ dikarenakan memiliki nilai Sig sebesar 0,421. Hal ini dikarenakan volume keramba yang dimiliki oleh pembudidaya Ikan Mas (Cyprinus carpio) Keramba Jaring Apung waduk PLTA Koto Panjang memiliki ukuran yang berbeda sehingga berbeda pula hasil panen yang di dapatkan oleh pembudidaya. Volume Keramba yang terdapat di Keramba Jaring Apung waduk PLTA Koto Panjang $6 \mathrm{~m} \times 6 \mathrm{~m} \times 4 \mathrm{~m}$ dan $6 \mathrm{~m} \times 8 \mathrm{~m} \times 4 \mathrm{~m}$, yang perbedaan ukuran tidak terlalu signifikan sehingga tidak mempengaruhi pendapatan.

\section{Hasil Panen Ikan Mas (Cyprinus carpio)}

Hasil panen Ikan Mas (Cyprinus carpio) yang diestimasi dalam penelitian ini merupakan total bobot Ikan Mas (Cyprinus carpio) yang dipanen perunit keramba selama 1 tahun pengelolaan. Hasil analisis regresi menunjukkan bahwa variabel hasil panen Ikan Mas (Cyprinus carpio) berpengaruh signifikan terhadap pendapatan pembudidaya pada taraf nyata $\alpha=5 \%$ karena memiliki nilai Sig sebesar 0,000.

Hal tersebut sesuai dengan hipotesis awal yang dibangun bahwa setiap peningkatan hasil panen Ikan Mas (Cyprinus carpio) diduga akan meningkatkan pendapatan pembudidaya Ikan Mas (Cyprinus carpio) keramba jaring apung Waduk PLTA Koto Panjang. Hal ini sesuai dengan penelitian Prasetio (2016) 
Semakin tinggi hasil panen maka pendapatan juga semakin tinggi.

\section{Lama Usaha}

Hasil analisis regresi menunjukkan bahwa variabel lama usaha berpengaruh pendapatan pembudidaya Ikan Mas (Cyprinus carpio) Keramba Jaring Apung waduk PLTA Koto Panjang. Variabel lama usaha tidak berpengaruh signifikan terhadap pendapatan pembudidaya Ikan Mas (Cyprinus carpio) Keramba Jaring Apung waduk PLTA Koto Panjang pada taraf nyata $\alpha=5 \%$ dikarenakan memiliki nilai Sig sebesar 0,504.

Variabel lama usaha tidak berpengaruh signifikan diduga karena pendapatan pembudidaya lebih dipengaruhi oleh seberapa banyak hasil panen yang dapat diperoleh dalam setiap tahun dan tidak terlalu dipengaruhi oleh seberapa lama pembudidaya melaksanakan usaha budidaya. Prasetio (2016).

\section{Jumlah Keramba}

Hasil analisis regresi menunjukkan bahwa variabel jumlah keramba berpengaruh pendapatan pembudidaya Ikan Mas (Cyprinus carpio) Keramba Jaring Apung waduk PLTA Koto Panjang. Variabel jumlah keramba berpengaruh signifikan terhadap pendapatan pembudidaya Ikan Mas (Cyprinus carpio) Keramba Jaring Apung waduk PLTA Koto Panjang. Pada taraf nyata $\alpha=5 \%$ dikarenakan memiliki nilai Sig sebesar 0,000. Variabel jumlah berpengaruh signifikan dikarenakan jumlah keramba mempengaruhi hasil panen dan juga mempengaruhi pendapatan, jumlah keramba yang dimiliki oleh pembudidaya Ikan Mas (Cyprinus carpio) Keramba Jaring Apung waduk PLTA Koto Panjang paling sedikit 5 unit dan paling banyak 431 unit keramba, sehingga sangat mempengaruhi terhadap pendapatan.

Analisis determinasi dalam regresi linear berganda digunakan untuk mengetahui prosentase sumbangan pengaruh variabel independen $\left(\mathrm{X}_{1}, \mathrm{X}_{2}, \mathrm{X}_{3}\right.$, $\mathrm{X}_{4}$ ) secara serentak terhadap variabel dependen $(\mathrm{Y})$. Berdasarkan angka $\mathrm{R}^{2}$ (R Square) sebesar 1,000 atau (100\%). Hal ini menunjukkan bahwa persentase sumbangan pengaruh variabel independen (Jumlah Keramba (Unit), Volume Keramba $\left(\mathrm{M}^{3}\right)$, Hasil Panen (Kg/ Tahun), Lama Usaha (Bulan), terhadap variabel dependen Y (Pendapatan) sebesar 100\%. Standard Error of the Estimate adalah suatu ukuran banyaknya kesalahan model regresi dalam memprediksikan nilai Y(Pendapatan). Dari hasil regresi di dapat nilai 0,005, hal ini berarti kecil kesalahan dalam prediksi pendapatan sebesar 0,005 .

Uji Koefisien Regresi Secara Bersama-sama (Uji F), untuk mengetahui apakah model regresi dapat digunakan untuk memprediksi variabel dependen atau tidak. Pengujian ini bertujuan untuk mengetahui pengaruh semua variabel independen yang terdapat dalam model secara bersama-sama terhadap variabel dependen Algifari, (2000). Signifikan berarti hubungan yang terjadi dapat berlaku untuk populasi (dapat digeneralisasikan). Dari hasil output analisis regresi dapat diketahui nilai $\mathrm{F}$ seperti pada tabel 2 berikut ini

Tabel 2. Hasil Uji F

\begin{tabular}{llrrrrr}
\hline \multicolumn{7}{c}{ ANOVA $^{\mathrm{a}}$} \\
Model & Sum Of Squares & df & Mean Square & F & Sig. \\
\hline \multicolumn{1}{c}{ Regression } & 36,180 & 4 & 9,045 & 402787,504 & $0,000^{\mathrm{b}}$ \\
& Residual & 0,001 & 37 & 0,000 & & \\
& Total & 36,181 & 41 & & & \\
\hline
\end{tabular}

a. Varibel Terikat: Pendapatan (Rp/ Tahun)

b. Prediktor: (Constant), Jumlah Keramba (Unit), Volume Keramba (M³), Hasil Panen (Kg/ Tahun), Lama Usaha (Bulan)

Berdasarkan tabel diperoleh $\mathrm{F}$ hitung sebesar 402787,504 Menentukan F tabel Dengan menggunakan tingkat keyakinan 95\%, $\alpha=5 \%$. Nilai Degree Of Freedom (df) yang didapatkan pada tabel diatas df (N1) sebesar $4-1=3$ dan df (N2) sebesar 42 $-4-1=37$, maka nilai $F$ tabel sebesar 2,86. Membandingkan $\mathrm{F}$ hitung dengan $\mathrm{F}$ tabel. Nilai $\mathrm{F}$ hitung $>$ F tabel $(402787,504>2,86$.

\section{Biaya Produksi Budidaya Pembesaran Ikan Mas (Cyprinus carpio) Keramba Jaring Apung PLTA Koto Panjang}

Hendrik, (2012) Total biaya produksi rata-rata merupakan penjumlahan dari modal kerja dengan biaya tidak tetap. Menurut Greenberg dalam Sinungan (2008) mendefinisikan produktivitas sebagai perbedaan antara kumpulan jumlah pengeluaran dan masukan yang dinyatakan dalam satu-satuan (unit) umum. Rata - rata biaya produksi Ikan Mas (Cyprinus carpio) Keramba Jaring Apung PLTA Koto Panjang bersifat tunai. 
Tabel 3. Rata - Rata Biaya Kegiatan Usaha Budidaya (Rp/Tahun)Budidaya Ikan Mas (Cyprinus Carpio) Keramba Jaring Apung Waduk PLTA Koto Panjang.

\begin{tabular}{|c|c|c|c|}
\hline \multicolumn{4}{|c|}{$\mathbf{C}$} \\
\hline \multicolumn{4}{|c|}{ Biaya Tetap (Rp/Tahun) } \\
\hline No & Komponen & $\begin{array}{c}\text { Nilai } \\
\text { (Rp/Unit/Tahun) } \\
\end{array}$ & $\begin{array}{c}\text { Pesentse } \\
(\%)\end{array}$ \\
\hline 1 & Biaya Penyusutan Mesin Gengset & $233.280,00$ & 0,11 \\
\hline 2 & Biaya Penyusutan Boat/Sampan & $912.680,55$ & 0,42 \\
\hline 3 & Biaya Penyusutan Keramba & $9.769 .600,00$ & 4,49 \\
\hline 4 & Biaya Penyusutan Rumah Jaga & $4.313 .757,78$ & 1,98 \\
\hline 5 & Biaya Gaji Pekerja & $18.000 .000,00$ & 8,27 \\
\hline 6 & BBM Genset dan Perawatan & $12.487 .500,00$ & 5,74 \\
\hline 7 & BBM Boat dan Perawatan & $9.900 .000,00$ & 4,55 \\
\hline \multicolumn{2}{|r|}{ Total Biaya Tetap (FC) } & $55.616 .818,33$ & 25,56 \\
\hline & & & \\
\hline \multicolumn{4}{|c|}{ Biaya variable (Rp/Tahun) } \\
\hline 1 & Benih Ikan Mas & $10.107 .142,86$ & 4,64 \\
\hline 2 & Pakan Ikan & $151.874 .832,86$ & 69,80 \\
\hline \multicolumn{2}{|r|}{ Total Biaya Variabel (VC) } & $161.981 .975,72$ & 74,44 \\
\hline & Biaya Total Produksi (TC) & $217.598 .794,05$ & 100,00 \\
\hline
\end{tabular}

Adapun untuk biaya tetap terdiri dari penyusutan mesin gengset, penyusutan boat/sampan, penyusutan keramba, penyusutan rumah jaga, biaya gaji pekerja, BBM genset dan perawatan serta BBM boat dan perawatan . sedangkan untuk biaya variabel yang terdiri dari biaya benih ikan mas dan pakan ikan mas, Biaya tetap produksi budidaya Ikan Mas (Cyprinus carpio) Keramba Jaring Apung waduk PLTA Koto Panjang rata - rata sebesar Rp. 55.616.818,33/tahun. Pengeluaran terbesar dari biaya tetap tersebut berasal dari upah tenaga kerja panen yaitu sebesar $\mathrm{Rp} 18.000 .000,00 /$ tahun atau 8,27\% dari total biaya produksi. Biaya variabel yang dikeluarkan pembudidaya Ikan Mas (Cyprinus carpio) Keramba Jaring Apung waduk PLTA Koto Panjang selama satu tahun. rata - rata sebesar Rp 161.981.975,72,-/tahun. Biaya pakan merupkakan komponen terbesar dari kegiatan budidaya Ikan Mas Keramba jaring apung hal ini sesuai dengan Wahyudy (2016) Komponen biaya terbesar terdapat pada biaya pakan. Artinya biaya pakan mempunyai peran yang besar dalam mempengaruhi biaya produksi. Hal tersebut juga didukung oleh Pomeroy et al. (2006) melaporkan bahwa benih, pakan dan tenaga kerja mencapai 61 . $74 \%$ dari total biaya produksi usaha budidaya.Penelitian yang dilakukan oleh Larastiti (2011) Faktor-faktor yang mempengaruhi besarnya nilai produksi yang diduga adalah, benih penebaran, penggunaan pupuk dan faktor penggunaan pakan tambahan. Biaya variabel tertinggi dihabiskan untuk membiayai pakan ikan sebesar Rp. 151.874.832,86 (Rp/Tahun), Kurnia \& Marinasari, (2005) menyatakan Biaya produksi pada budidaya sistem KJA meliputi biaya yang dikeluarkan untuk sarana produksi perikanan, yaitu pakan, benih, retribusi, serta upah tenaga kerja. Biaya produksi yang paling berpengaruh adalah biaya pakan dan benih ikan.

\section{Analisis Penerimaan}

Penerimaan (inflow) adalah segala sesuatu yang dihasilkan oleh suatu kegiatan yang menggunakan sejumlah biaya. Mulyadi, 2015. Berdasarkan data hasil perhitungan pada diperoleh penerimaan atau nilai produksi dari Ikan Mas (Cyprinus carpio) Keramba Jaring Apung Waduk PLTA Koto Panjang rata - rata produksi $3.200,60 \mathrm{~kg} / \mathrm{unit} / \mathrm{tahun}$ dengan berat panen berkisar \pm 500 gram/ekor. Penerimaan total diperoleh Hasil produksi Ikan Mas yang dihasilkan adalah sebanyak 95\% dari jumlah benih yang ditebar adalah sebesar Rp.240.044.642,86,- /unit/tahun rata - rata pembudidaya Ikan Mas (Cyprinus carpio) Keramba Jaring Apung waduk PLTA Koto Panjang memiliki lebih dari 4 unit keramba. Sedangkan Rachmawati, (2017) Penerimaan atau total revenue (TR) tertinggi pada pembudidaya ikan keramba jaring apung $d i$ Waduk Sutami adalah senilai Rp.209.000.000,00, sedangkan Sumantri, (2005) Rata -rata penerimaan

pembudidaya ikan mas sistem keramba jaring apung selama satu kali proses produksi adalah sebesar Rp. 107.461.246,06/MP. Penerimaan budidaya ikan kerambah jaring apung Waduk PLTA Koto panjang jauh lebih besar.

Adanya perbedaan jumlah penerimaan usaha ikan mas sistem keramba jaring apung dipengaruhi oleh jumlah produksi yang dihasilkan dalam tiap musim panen, dimana semakin tinggi produksi maka penerimaan juga akan semakin tinggi sedangkan tinggi rendahnya produksi yang dihasilkan dipengaruhi oleh luas dan jumlah keramba yang dimiliki oleh pembudidaya ikan mas sistem keramba jaring apung.

Analisis Pendapatan Usaha

Pendapatan bersih atau laba adalah pendapatan dikurangi biaya variable ditambah biaya tetap ditambah penyusutan ditambah biaya perawatan 
(Hudaya \& Masri, 2015).Dalam sebuah cashflow, inflow merupakan segala sesuatu yang dapat meningkatkan pendapatan sebuah usaha (Hamdani, 2014).Pendapatan bersih yang di terimah oleh pembudidaya Ikan Mas (Cyprinus Carpio) Keramba Jaring Apung waduk PLTA Koto Panjang merupakan selisih penerimaan dengan semua biaya produksi adapaun pendapatan yang diterimah oleh pembudidaya Ikan Mas (Cyprinus Carpio) Keramba Jaring Apung waduk PLTA Koto Panjang merupakan pendapatan yang dihasilkan dari Total penerimaan (TR) kegiatan usaha budidaya Rp/Unit/Tahun dikurangi dengan Total biaya kegiatan (TC) usaha budidaya Rp/Unit/Tahun, sehingga diketahui bahwa pendapatan $(\pi)$ rata - rata pembudidaya Ikan Mas (Cyprinus Carpio) Keramba Jaring Apung waduk PLTA Koto Panjang sebesar Rp.22.445.848,81,-/unit/tahun, hasil ini didapatkan dari Total Penerimaan budidaya
Ikan Mas (Cyprinus Carpio) Keramba Jaring Apung waduk PLTA Koto Panjang (TR) sebesar Rp. 240.044.642,86,- Unit/Tahun dikurangai total biaya kegiatan budidaya Ikan Mas (Cyprinus Carpio) Keramba Jaring Apung waduk PLTA Koto Panjang (TC) sebesar Rp 217.598.794,05,-unit/tahun. Biaya total biaya kegiatan budidaya Ikan Mas (Cyprinus Carpio) Keramba Jaring Apung waduk PLTA Koto Panjang (TC) tergolong tinggi dikarenakan biaya tersebut sudah termasuk biaya pakan, dalam usaha budidaya harga pakanlah yang tinggi.

\section{Analisis Surplus Produsen}

Berdasarkan surplus produsen untuk mengestimasi total nilai ekonomi pemanfaatan kawasan budidaya Ikan Mas (Cyprinus carpio) Keramba Jaring Apung waduk PLTA Koto Panjang dapat dilihat pada Tabel 4.

Tabel 4. Nilai Ekonomi Pemanfaatan Kawasan Budidaya Ikan Mas (Cyprinus Carpio) Keramba Jaring Apung Waduk PLTA Koto Panjang.

\begin{tabular}{lll}
\hline No & Komponen & Nilai (Rupiah) \\
\hline 1 & Hasil Produksi Panen (Unit / Tahun) & $240.044 .642,86$ \\
2 & Biaya Produksi (Unit / Tahun) & \\
& a) Biaya Tetap & $55.616 .818 ., 33$ \\
& b) Biaya Variabel & 161.981 .975 .72 \\
& c) Total Biaya Produksi & $217.598 .794,05$ \\
3 & Surplus Produsen (Unit / Tahun) & $23.880 .093,03$ \\
\hline \multicolumn{2}{l}{ Total Nilai Ekonomi / Tahun } & $\mathbf{3 8 . 9 2 4 . 4 6 3 . 6 2 2 , 1 0}$ \\
\hline
\end{tabular}

Berdasarkan hasil estimasi yang disajikan pada Tabel 4 diatas, diketahui bahwa nilai surplus produsen budidaya Ikan Mas (Cyprinus Carpio) Keramba Jaring Apung waduk PLTA Koto Panjang perunit keramba sebesar Rp. 23.880.093,03/unit/tahun. Dengan total biaya produksi Rp. 217.598.794,05, biaya tersebut adalah biaya total (jumlah dari biaya tetap dan biaya variabel). Secara keseluruhan jika semua areal keramba yang dikelola oleh pembudidaya responden di waduk PLTA Koto Panjang dimanfaatkan dan berproduksi untuk usaha budidaya Ikan Mas (Cyprinus Carpio) Keramba Jaring Apung waduk PLTA Koto Panjang tersebut, maka total nilai ekonomi dari pemanfaatan kawasan budidaya Ikan Mas (Cyprinus Carpio) Keramba Jaring Apung waduk PLTA Koto Panjang mencapai Rp. 38.924.463.622,10,-/tahun. Nilai surplus produsen tersebut jauh lebih besar di bandingkan Surplus produsen yang diterima pembudidaya ikan keramba di Desa Tambak sari yang hanya mencapai Rp 1.650.856.722,91/tahun Prasetio, (2016). Nilai surplus produsen tersebut menjadi gambaran nilai kontribusi kawasan terhadap usaha budidaya Ikan Mas (Cyprinus Carpio) Keramba Jaring Apung waduk PLTA Koto Panjang. Berdasarkan perhitungan tersebut, aktivitas budidaya Ikan Mas (Cyprinus Carpio) Keramba Jaring Apung waduk PLTA Koto Panjang layak untuk dikembangkan secara lebih maksimal karena telah memberikan kesempatan pembudidaya untuk memperoleh pendapatan yang lebih tinggi. Penelitian yang dilakukan oleh Rachmawati, (2017). Biaya produksi pada usaha budidaya ikan nila keramba jaring apung di Waduk Sutami menunjukkan bahwa biaya produksi tertinggi adalah senilai Rp.78.905.167,00 dengan faktor produksi berupa pakan mencapai Rp.59.250.000,00. Ini jauh lebih kecil dibadingkan biaya produsi usaha budidaya ikan mas kerambah jaring apung Waduk PLTA Koto Panjang

\section{Analisis Kelayakan Finansial Usaha Budidaya Ikan Mas (Cyprinus Carpio) Keramba Jaring Apung Waduk PLTA Koto Panjang}

Hasil perhitungan analisis jangka panjang dalam keadaan normal pada usaha budidaya ikan mas (Cyprinus Carpio) keramba jaring apung PLTA Koto Panjang berdasarkan dua jenis kerambah menghasilkan nilai Net Present Value (NPV) positif yang berarti usaha tersebut menggambarkan nilai bersih sekarang menguntungkan lebih besar dari nol yaitu sebesar Rp 122.990.016,52,-/unit untuk volume keramba $6 \times 6 \times 4$. Sedangkan untuk volume keramba $6 \times 8 \times 4$ memiliki nilai Net Present Value yang jauh lebih besar sebesar Rp. 196.202.384,48,-/unit. Hal ini dikarenakan keramba dengan ukuran 6 x 8 x 4 memiliki benefit yang jauh lebih besar dibandingkan benefit keramba dengan ukuran $6 \times 6 \times 4$. (Tabel 5) 
Tabel 5. Analisis Jangka Panjang dalam Keadaaan Normal Pada Usaha Ikan Mas (Cyprinus Carpio) Keramba Jaring Apung PLTA Koto Panjang

\begin{tabular}{|c|c|c|c|c|c|c|}
\hline No & Tahun & Cost & Benefit & Df $6 \%$ & Net Benefit & PV Net Benefit \\
\hline \multicolumn{7}{|c|}{ Volume Keramba 6 × 6 × 4} \\
\hline 1 & 1 & $251.435 .780,00$ & $213.750 .000,00$ & 0,94340 & $(37.685 .770,00)$ & $(35.552 .613,21)$ \\
\hline 2 & 2 & $184.620 .780,00$ & $213.750 .000,00$ & 0,89000 & $29.129 .230,00$ & $25.924 .911,00$ \\
\hline 3 & 3 & $198.300 .780,00$ & $213.750 .000,00$ & 0,83962 & $15.449 .230,00$ & $12.971 .471,42$ \\
\hline 4 & 4 & $184.620 .780,00$ & $213.750 .000,00$ & 0,79209 & $29.129 .230,00$ & $23.073 .078,50$ \\
\hline 5 & 5 & $198.300 .780,00$ & $213.750 .000,00$ & 0,74726 & $15.449 .230,00$ & $11.544 .563,38$ \\
\hline 6 & 6 & $187.620 .780,00$ & $213.750 .000,00$ & 0,70496 & $26.129 .230,00$ & $18.420 .076,10$ \\
\hline 7 & 7 & $198.300 .780,00$ & $213.750 .000,00$ & 0,66506 & $15.449 .230,00$ & $10.274 .620,31$ \\
\hline 8 & 8 & $184.620 .780,00$ & $213.750 .000,00$ & 0,62741 & $29.129 .230,00$ & $18.276 .039,27$ \\
\hline 9 & 9 & $198.300 .780,00$ & $213.750 .000,00$ & 0,59190 & $15.449 .230,00$ & $9.144 .375,50$ \\
\hline 10 & 10 & $184.620 .780,00$ & $236.400 .434,57$ & 0,55839 & $51.779 .664,57$ & $28.913 .494,25$ \\
\hline NPV & & $122.990 .016,52$ & & & & \\
\hline BCR & & 1,10 & & & & \\
\hline IRR & & $62,97 \%$ & & & & \\
\hline \multicolumn{7}{|c|}{ Volume Keramba 6 × 8 × 4} \\
\hline 1 & 1 & $278.652 .400,00$ & $249.375 .000,00$ & 0,94340 & $(29.277 .390,00)$ & $(27.620 .179,25)$ \\
\hline 2 & 2 & $208.667 .400,00$ & $249.375 .000,00$ & 0,89000 & $40.707 .610,00$ & $36.229 .627,98$ \\
\hline 3 & 3 & $225.517 .400,00$ & $249.375 .000,00$ & 0,83962 & $23.857 .610,00$ & $20.031 .309,40$ \\
\hline 4 & 4 & $208.667 .400,00$ & $249.375 .000,00$ & 0,79209 & 40.707.610,00 & $32.244 .239,93$ \\
\hline 5 & 5 & $225.517 .400,00$ & $249.375 .000,00$ & 0,74726 & $23.857 .610,00$ & $17.827 .794,06$ \\
\hline 6 & 6 & $211.667 .400,00$ & $249.375 .000,00$ & 0,70496 & $37.707 .610,00$ & $26.582 .377,12$ \\
\hline 7 & 7 & $225.517 .400,00$ & $249.375 .000,00$ & 0,66506 & $23.857 .610,00$ & $15.866 .673,24$ \\
\hline 8 & 8 & $208.667 .400,00$ & $249.375 .000,00$ & 0,62741 & $40.707 .610,00$ & $25.540 .458,12$ \\
\hline 9 & 9 & $225.517 .400,00$ & $249.375 .000,00$ & 0,59190 & $23.857 .610,00$ & $14.121 .282,70$ \\
\hline 10 & 10 & $208.667 .400,00$ & $272.025 .434,57$ & 0,55839 & $63.358 .044,57$ & $35.378 .801,16$ \\
\hline NPV & & $196.202 .384,48$ & & & & \\
\hline BCR & & 1,13 & & & & \\
\hline IRR & & $124,75 \%$ & & & & \\
\hline
\end{tabular}

Perbedaan benefit yang didapatkan terdapat pada jumlah panen ikan yang jauh lebih besar. Sedangkan perbedaan pada nilai cost antara kedua keramba terdapat pada kebutuhan pakan. Nilai tersebut menunjukkan bahwa usaha layak untuk dilaksanakan secara finansial. Nilai Benefit Cost Ratio (BCR) yang diperoleh dari hasil perhitungan adalah 1,10 untuk volume keramba $6 \times 6 \times 4$ dan nilai Benefit Cost Ratio $(B C R)$ keramba ukuran 6 × 8 × 4 sebesar 1,13 . Hal tersebut menunjukkan bahwa penggunaan investasi memenuhi ukuran kelayakan berdasarkan kriteria investasi yaitu usaha layak dilaksanakan jika nilai Benefit Cost Ratio (BCR) lebih besar sama dengan 1. Nilai Benefit Cost Ratio (BCR) sebesar 1,10 untuk volume keramba $6 \times 6 \times 4$ menunjukkan bahwa setiap pengeluaran biaya sebesar $\mathrm{Rp} 1$ akan menghasilkan manfaat bersih sebesar $\mathrm{Rp} \mathrm{1,10.} \mathrm{Sedangkan} \mathrm{volume}$ keramba 6 × 8 × 4 nilai Benefit Cost Ratio (BCR) sedikit lebih besar sebesar 1,13 yang artinya setiap pengeluaran biaya sebesar $\mathrm{Rp} 1$ akan menghasilkan manfaat bersih sebesar $\mathrm{Rp} 1,13$.

Ukuran kriteria investasi lainnya yaitu Internal Rate of Return (IRR). Internal Rate of Return (IRR) yang diperoleh dari usaha budidaya ikan mas (Cyprinus Carpio) keramba jaring apung PLTA Koto Panjang dengan dua volume keramba memiliki nilai Internal Rate of Return (IRR) yang jauh berbeda sebesar 62,97\% untuk volume keramba 6 × 6 × 4 sedangkan untuk volume keramba 6 × 8 × 4 sebesar 124,75\%. Nilai tersebut menunjukkan bahwa penggunaan investasi pada usaha tersebut lebih baik atau dapat memberikan keuntungan internal sebesar 62,97\%/tahun untuk volume keramba $6 \times 6 \times 4$ dan $124,75 \%$ /tahun untuk volume keramba $6 \times 8 \times 4$. Nilai tersebut lebih besar dari pada tingkat discount rate yang digunakan yaitu 6 $\%$ sehingga dapat dikatakan bahwa usaha layak secara finansial untuk dikembangkan dan dilaksanakan. Berdasarkan analisis kelayakan finansial tersebut, nilai Net Present Value (NPV), Benefit Cost Ratio (BCR), dan Internal Rate of Return (IRR) yang diperoleh telah memenuhi ukuran kelayakan berdasarkan criteria investasi.

Penelitian yang dilakukan oleh Gandhy, (2017) pada usaha budidaya ikan pada Keramba Jaring Apung yang dilakukan di Waduk Cirata pada umumnya membudidayakan ikan Mas dan Nila memiliki Net Present Value (NPV) sebesar Rp 136.976.675.Nilai Net Present Value (NPV)untuk volume keramba 6 × 6 × 4 sebesar Rp 77.136.617,10,/unit jauh lebih kecil dibandingkan dengan Net Present Value (NPV) Waduk Ciratabernilai Net Present Value (NPV) sebesar Rp 136.976.675. Akan tetapi dengan ukuran keramba $6 \times 8 \times 4$ memiliki nilai Net Present Value yang jauh lebih jauh lebih besar sebesar Rp.173.394.632,39,-/unit. Berdasarkan

Hasil penelitian Jayalaksana, (2016) Perhitungan analisis finansial usaha budidaya pembesaran ikan mas sistem kolam air deras di Kecamatan Cijambe Kabupaten Subang memiliki ratarata keuntungan sebesar Rp.60.913.860 per musim pemeliharaan. 


\section{Analisis Sensitivitas}

Analisis sensitivitas merupakan suatu kegiatan menganalisis kembali rencana proyek yang dipengaruhi unsur -unsur ketidak pastian yang akan terjadi dimasa mendatang. Anwar, (2018) Parameter yang digunakan untuk melihat sentivitas usaha budidaya ikan mas (Cyprinus carpio) keramba jaring apung PLTA Koto Panjang berupa penurunan harga jual jual ikan mas (Cyprinus carpio) sebesar $5 \%$ dan peningkatan harga pakan ikan mas (Cyprinus carpio) sebesar $10 \%$ (Tabel 6)

Tabel 6. Hasil Analisis Sensitivitas Usaha Budidaya Ikan Mas (Cyprinus Carpio) Keramba Jaring Apung PLTA Koto Panjang

\begin{tabular}{|c|c|c|c|c|c|}
\hline No & $\begin{array}{l}\text { Parameter } \\
\text { Perubahan }\end{array}$ & $\begin{array}{l}\text { Persentase } \\
\text { Perubahan }\end{array}$ & $\begin{array}{l}\text { NPV } \\
\text { (Rp) }\end{array}$ & BCR & IRR \\
\hline \multicolumn{6}{|c|}{ Volume Keramba 6 x 6 x 4} \\
\hline 1 & $\begin{array}{l}\text { Penurunan harga jual } \\
\text { Ikan Mas }\end{array}$ & $5 \%$ & $44.329 .086,16$ & 1,04 & $47,27 \%$ \\
\hline 2 & $\begin{array}{l}\text { Peningkatan harga } \\
\text { Pakan Ikan Mas }\end{array}$ & $10 \%$ & $23.457 .145,21$ & 1,03 & $35,83 \%$ \\
\hline \multicolumn{6}{|c|}{ Volume Keramba $6 \times 8 \times 4$} \\
\hline 3 & $\begin{array}{l}\text { Penurunan harga jual } \\
\text { Ikan Mas }\end{array}$ & $5 \%$ & $104.431 .299,06$ & 1,07 & $114,24 \%$ \\
\hline 4 & $\begin{array}{l}\text { Peningkatan harga } \\
\text { Pakan Ikan Mas }\end{array}$ & $10 \%$ & $80.075 .004,58$ & 1,06 & $108,35 \%$ \\
\hline
\end{tabular}

Tabel 6 menunjukkan bahwa pada kondisi penurunan harga jual ikan mas (Cyprinus Carpio) dengan membedakan dua volume keramba memiliki perbedaan yang sangat siginifikan antara keduanya. Untuk volume keramba 6 x 6 x $\quad \begin{array}{llll}4 & \text { jika terjadi }\end{array}$ penurunan harga jual ikan mas sebesar $5 \%$ akan menghasilkan nilai Net Present Value (NPV), Rp. 44.329.086,16-, dengan nilai Benefit Cost Ratio (BCR) 29,61 dan Internal Rate of Return (IRR) sebesar 47,27\%. Perubahan peningkatan harga pakan sebesar $10 \%$ menghasilkan nilai Net Present Value (NPV) sebesar Rp. 23.457.145,21,- dengan nilai Benefit Cost Ratio (BCR) 1,03 dan Internal Rate of Return (IRR) sebesar 35,83\%. Sedangkan volume keramba 6 × 8 × 4 jika terjadi penurunan harga jual ikan mas sebesar $5 \%$ akan menghasilkan nilai Net Present Value (NPV) sebesar Rp. 104.431.299,06,- dengan nilai Benefit Cost Ratio (BCR) 1,07 dan Internal Rate of Return (IRR) sebesar 114,24\% perubahan peningkatan harga pakan sebesar $10 \%$ pada keramba menghasilkan nilai Net Present Value (NPV) sebesar Rp. 80.075.004,58,- dengan nilai Benefit Cost Ratio (BCR) 1,06 dan Internal Rate of Return (IRR) sebesar $108,35 \%$.

Hasil analisis sensitivitas tersebut telah menunjukkan bahwa pada kondisi terjadi perubahan penurunan harga jual ikan mas (Cyprinus carpio) dapat memberikan pengaruh yang signifikan terhadap perubahan nilai kriteria kelayakan investasi usaha budidaya budidaya ikan mas (Cyprinus carpio) keramba jaring apung PLTA Koto Panjang.

\section{Alternatif Kebijakan Pengembangan Usaha Budidaya Ikan Mas (Cyprinus carpio) Keramba Jaring Apung waduk PLTA Koto Panjang}

Penerapan MPE hasil alternatif akan ditentukan dari total nilai yang didapatkan dari penjumlahan konversi nilai setiap kriteria dan sub kriteria kemudian dipangkatkan dengan tingkat kepentingan setiap kriteria (bobot) yang telah ditentukan pengambil keputusan. Borman, (2018).

Setelah mendapatkan nilai metode perbandingan eksponensial (MPE), maka dapat dilihat urutan peringkat dari ke tiga alternatif kebijakan pengembangan budidaya Ikan Mas (Cyprinus carpio) Keramba Jaring Apung Waduk PLTA Koto Panjang. Penguatan modal dan peningkatan sarana serta prasarana terkait pengembangan budidaya Ikan Mas (Cyprinus carpio) diperingkat 1 dan pengembangan usaha pasca panen yang menciptakan produk olahan dari hasil perikanan diperingkat 2 sedangkan untuk alternatif pengembangan usaha terkait produksi pakan secara mandiri diperingkat ke 3 dikarenakan memiliki nilai metode perbandingan eksponensial (MPE) terendah (Tabel 7 ).

Tabel 7. Penentuan Peringkat Alternatif Kebijakan Pengembangan Budidaya Ikan Mas (Cyprinus Carpio)

\begin{tabular}{clcc}
\multicolumn{2}{c}{ Keramba Jaring Apung Waduk PLTA Koto Panjang } & \multicolumn{1}{c}{ Alternatif Kebijakan Pengembangan } & Peringkat \\
\hline No & \multicolumn{1}{c}{ Nengembangan usaha pasca panen yang menciptakan produk } \\
1 & $\begin{array}{l}\text { Olahan dari hasil perikanan } \\
\text { Penguatan modal dan peningkatan sarana serta prasarana terkait } \\
\text { pengembangan budidaya ikan } \\
\text { Melakukan Pengembangan usaha terkait produksi pakan secara } \\
\text { mandiri }\end{array}$ & 33.139 & 2 \\
3 & 15.605 & 3 \\
\hline
\end{tabular}


Diperoleh alternatif kebijakan pengembangan yang terbaik untuk dikembangkan dan dilaksanakan adalah penguatan modal dan peningkatan sarana serta prasarana terkait pengembangan budidaya ikan. Alternatif tersebut berada pada urutan pertama berdasarkan dari perhitungan nilai total MPE. Penguatan modal dan peningkatan sarana serta prasarana terkait pengembangan budidaya ikan keramba jaring apung yang terbaik untuk dikembangkan dan dilaksanakan di kawasan Waduk PLTA Koto Panjang. Kebijakan tersebut dipandang sebagai alternatif yang paling tepat untuk dikembangkan karena terdapat potensi pemanfaatan secara lebih optimal areal keramba di kawasan Waduk PLTA Koto Panjang untuk pelaksanaan budidaya ikan Keramba Jaring Apung.

\section{SIMPULAN}

Berdasarkan hasil penelitian yang telah dijelaskan sebelumnya, maka dapat diambil kesimpulan sebagai berikut:

Faktor - faktor yang berpengaruh nyata terhadap pendapatan pembudidaya Ikan Mas (Cyprinus carpio) Keramba Jaring Apung waduk PLTA Koto Panjang adalah Hasil Panen (HP) $\mathrm{kg} / \mathrm{unit}$ dan Jumlah Keramba (JK) Unit. Nilai surplus produsen budidaya Ikan Mas (Cyprinus Carpio) Keramba Jaring Apung waduk PLTA Koto Panjang per unit keramba sebesar Rp. 23.880.093,03/tahun, sedangkan total nilai ekonomi dari pemanfaatan kawasan budidaya Ikan Mas (Cyprinus Carpio) Keramba Jaring Apung waduk PLTA Koto Panjang mencapai Rp 38.924.463.622,10,/tahun.

Usaha budidaya Ikan Mas (Cyprinus carpio) keramba jaring apung Waduk PLTA Koto Panjang layak untuk dikembangkan. Usaha budidaya Ikan Mas (Cyprinus carpio) keramba jaring apung waduk PLTA Koto Panjang lebih sensitiv terhadap perubahan penurunan produksi ikan mas (Cyprinus carpio) dibandingkan perubahan penurunan harga pakan ikan mas (Cyprinus carpio). Alternatif kebijakan pengembangan yang terbaik untuk dikembangkan dan dilaksanakan adalah penguatan modal dan peningkatan sarana serta prasarana terkait pengembangan budidaya ikan.

\section{UCAPAN TERIMA KASIH}

Penulis mengucapkan terima kasih atas bantuan berbagai pihak yang telah memberikan dukungan terhadap penelitian ini.

\section{DAFTAR PUSTAKA}

Anwar, M. S., Hasyim, A. I., \& Affandi, M.I. (2018). Analisis kelayakan finansial usaha pembibitan lada di desa sukadana baru kecamatan marga tiga kabupaten lampung timur. Jurnal JIIA, Volume 6 No. 2, Mei 2018

Algifari. (2000). Analisis Regresi : Teori, Kasus, dan Solusi. Edisi 2. BPFE.Yogyakarta
Borman, R.I. \& Helmi, F. (2018) Penerapan metode perbandingan eksponensial (MPE) dalam sistem pendukung keputusan penerima beasiswa siswa berprestasi pada SMK XYZ. CESS (Journal of Computer Engineering System and Science) Vol. 3 No.1Januari2001https://doi.org/10.24114/cess.v3i 1.8227

BPS, Kampar. (2010). Kampar dalam Angka 2010. BPS Kabupaten Kampar. Bangkinang.

Djajadiningrat. (2011). Perpajakan Indonesia. Jakarta: Salemba Empat.

Firdaus, M. (2004). Ekonometrika suatu Pendekatan Aplikatif. Jakarta: Bumi. Aksara.

Gandhy, A. (2017). Analisis Peningkatkan Pendapatan Petani Keramba Jaring Apung dengan Diversifikasi Spesies Ikan Budidaya Di Waduk Cirata. Jurnal Ekonomi \& Studi Pembangunan Volume,18 Nomor 1, April 2017, Hlm.25-33. https://doi.org/10.18196/jesp.18.1.3778

Hamdani. (2014). Analisis Kelayakan Usaha Pembesaran Kepiting Soka di Balai Pengembangan Budidaya Air Payau dan Laut (BPBAPL) Karawang, Kabupaten Karawang [skripsi]. Bogor (ID): Institut Pertanian Bogor.

Hendrik. (2012). Analisis Usaha Dan Potensi Pengembangan Keramba Jaring Apung (Kja) Di Waduk Plta Koto Panjang Kabupaten Kampar Provinsi Riau. Jurnal Berkala Perikanan Terubuk, Februari 2012, Hlm 45 - 51 Issn 0126 - 4265

Hudaya, A., Masri, Z. (2015). Analisis Ekonomi Usaha Budidaya Ikan Kerapu Di Pulau Tidung Kepulauan Seribu Dki Jakarta. 1 (1). ISSN : 24425532. 227 hal.

Jayalaksana, M.R., Handaka, A. A., \& Subhan, U. (2016). Keragaan Produksi Dan Evaluasi Usaha Pembesaran Ikan Mas (Cyprinus carpio) Pada Sistem Kolam Air Deras (Studi Kasus Di Kecamatan Cijambe Kabupaten Subang). Jurnal Perikanan Kelautan Vol. VII No. 1 /Juni 2016 (84-92)

Jhingan, M.L., (2004). Ekonomi Pembangunan dan Perencanaan", Terjemahan oleh D. Guritno, Edisi ke-1, Cetakan ke-10, PT. Raja Grafindo Persada,. Jakarta.

Juanda, B. (2009). Metodologi Penelitian Ekonomi dan Bisnis Edisi Kedua. IPB. PRESS, Bogor.

Karunia, S., \& Marinasari, R. (2015). Analisis Biaya Eksternalitas Limbah Pakan Usaha Keramba Jaring Apung Di Waduk Jatiluhur Kabupaten Purwakarta. Buletin Ilmiah "MARINA" Sosek Kelautan dan Perikanan Vol. 1 No. 2 Tahun 2015: 77-88 https://doi.org/10.15578/marina.v1i2.2074

Kukuh, T. (2013). Analisis Pendapatan Dan Efisiensi Produksi Usahatani Budidaya Pembesaran Ikan Mas dan Nila Pada Keramba Jaring Apung Ganda [skripsi]. Bogor (ID): Institut Pertanian Bogor

Maghfiroh., \& Nurul, M. (2010). Aplikasi Teknik Pengambilan Keputusan dalam Manajemen. Rantai pasok. Bogor: PT. Penerbit IPB Press.

Mulyadi, M.Y. (2015). Analisis Finansial Budidaya Ikan dalam Karamba Jaring apung di Sungai Melawi Kecamatan Pinoh Utara kabupaten 
Melawi. Jurnal Social Economic Of Agriculture,Volume 4, Nomor 1, April 2015.

Pomeroy, R.S., Parks, J.E., Balboa, C.M. (2006). Farming the reef: is aquaculture a solution for reducing fishing pressure on coral reef ? Marine Policy.

Prasetio, T. (2016) Estimasi Nilai Ekonomi dan Analisis Kelayakan Usaha Budidaya Tambak Polikultur (Studi Kasus: Desa Tambaksari, Kecamatan Tirtajaya, Kabupaten Karawang) [skripsi]. Bogor (ID): Institut Pertanian Bogor.

Rachmawati, A. (2017) Nilai Ekonomi Usaha Perikanan Keramba Jaring Apung Di Waduk Sutami Desa Karangkates, Kecamatan Sumberpucung, Kabupaten Malang, Jawa Timur. Sarjana thesis, Universitas Brawijaya

Rangkuti, F. (2004). Manajemen Persediaan Aplikasi di Bidang Bisnis. Jakarta: PT. Raja Grafindo Persada.

Sinungan, M. (2008). Produktivitas apa dan Bagaimana. Bumi Aksara. Jakarta. 154 hal.
Sumantri, B. (2005). Analisis Pendapatan Usaha Ikan Mas sistem Keramba Jaring Apung dan Pemasarannya di Kabupaten Simalungun. Jurnal AGRISEP Vol. 4 Nomor 1, September 2005: 17-27 https://doi.org/10.31186/jagrisep.4.2.17-27

Soeharto, I. (1997). Manajemen Proyek dari Konseptual Sampai Operasional. Erlanga, Jakarta.

Soekartawi. (2002). Ilmu Usahatani. Universitas Indonesia Press. Jakarta.

Wahyudy, H. A. (2016). Optimasi Usaha Budidaya Ikan Air Tawar Pada Kerambajaring Apung Di Waduk PLTA Koto Panjang Kabupaten Kampar provinsi Riau. Jurnal Agribisnis Vol: 18 Nomor. 1 Juni 2016 ISSN-P: 1412-4807 ISSN O: 2503-4375 https://doi.org/10.31849/agr.v18i1.752

Wiraningsih, T. (2016) Model Dinamik Pengelolaan Jasa Ekosistem Waduk Koto PanjangKabupaten Kampar Riau. Jurnal Omni-Akuatika Vol. 12 No. 2 November2016https://doi.org/10.20884/1.oa.201 6.12.2.103 